\title{
DESEJO DE LIBERDADE
}

O pássaro abre suas asas

Dentro da gaiola fechada

Ele olha

Olha para além do céu

Com o seu pequeno coração apertado

Ele queria voar

Ele queria saber ao menos o que é amar

Mas trancado

O pássaro abre suas asas

Procurando a chave do seu coração

Procurando a chave dessa sua prisão

Batiam apressadas

As asas da libertação

Sonhando com o abraço do infinito

Onde se cruzam céu e mar.

Elara Araújo Moretz-Sohn ${ }^{1}$

\footnotetext{
${ }^{1}$ Estudante da $1^{\text {a }}$ série do Ensino Médio do Instituto Dom Barreto (IDB), em Teresina (PI).
} 